\title{
Evaluating Winter-sown Onion Entries for Iris yellow spot virus Susceptibility
}

\author{
Mohsen Mohseni-Moghadam ${ }^{1}$ and Christopher S. Cramer ${ }^{2,5}$ \\ Department of Plant and Environmental Sciences, Box 30003, MSC 3Q, New \\ Mexico State University, Las Cruces, NM 88003-8003
}

\author{
Robert L. Steiner ${ }^{3}$ \\ Department of Economics and International Business, Box 30001, MSC 3CQ, \\ New Mexico State University, Las Cruces, NM 88003-8001
}

\begin{abstract}
Rebecca Creamer ${ }^{4}$
Department of Entomology, Plant Pathology, and Weed Science, Box 30003, MSC 3BE, New Mexico State University, Las Cruces, NM 88003-8003
\end{abstract}

Additional index words. Allium cepa, disease rating, ELISA, RT-PCR

\begin{abstract}
Iris yellow spot virus (IYSV) causes a foliar disease in onion (Allium cepa L.) that results in a reduction in bulb size. Currently, no IYSV-tolerant or -resistant cultivar exists and a genetic source for tolerance or resistance has not been identified. Because other disease control methods are limited, host plant resistance offers the best hope to combat this disease. In this study, 13 winter-sown onion entries were screened for iris yellow spot (IYS) symptoms during the 2007 and 2008 cropping seasons. Twenty plants from each plot were observed and rated weekly during the growing seasons for strawcolored, necrotic lesions, typical of IYSV infection. Collected plant samples were assayed for IYSV by enzyme-linked immunosorbent assay (ELISA) and reverse-transcription polymerase chain reaction (RT-PCR). Visual rating was done using a scale of 1 to 9 with 1 representing no symptomatic tissue and 9 representing more than $50 \%$ tissue damage. Two different plant sampling methods were used in disease rating to determine their effect on mean severity and to correlate disease severity with absorbance values. Of the entries tested, plants of NMSU 05-33-1 exhibited a delay in symptom expression and lower IYSV levels relative to plants of other entries. Plants of 'Denali' and 'Gelma' appeared to be more susceptible to IYSV than plants of other entries. Plant selection within the plot over time did not influence disease rating values. When the same plants were rated and sampled for IYSV using ELISA, there was a strong, positive correlation between rating and absorbance values.
\end{abstract}

Since 2001, IYSV has been confirmed in all onion-producing states in the western United States, including Arizona, California, Colorado, Idaho, New Mexico, Nevada, Oregon, Utah, and Washington (Creamer et al., 2004; Crowe and Pappu, 2005; du Toit et al., 2004a; Hall et al., 1993; Pappu and Matheron, 2008; Poole et al., 2007; Schwartz et al., 2002) as well as in Georgia (Mullis et al., 2004), Texas (Miller et al., 2006), and New York (Hoepting et al., 2007). An IYSV epidemic in Colorado during 2003 is estimated to have cost growers $\$ 2.5$ to $\$ 5.0$ million in farm receipts alone

\footnotetext{
Received for publication 13 Apr. 2011. Accepted for publication 25 June 2011.

This research was funded in part by the New Mexico Dry Onion Commission and the New Mexico Agricultural Experiment Station.

We acknowledge the technical assistance of Dr. Rejah Muhyi and thank Nunhems USA, Sakata Seed America, Inc., and Seminis Vegetable Seeds, Inc. for the donation of onion seed.

${ }^{1}$ Graduate research assistant.

${ }^{2}$ Professor of Horticulture.

${ }^{3}$ Professor of Applied Statistics.

${ }^{4}$ Associate Professor of Plant Virology.

${ }^{5}$ To whom reprint requests should be addressed; e-mail cscramer@nmsu.edu.
}

to the effects of these insecticides. In several different onion production areas, thrips resistance to several insecticides has been detected (MacIntyre Allen et al., 2005; Martin et al., 2003; Shelton et al., 2003). As the vector becomes more difficult to control, the prevalence of IYSV and the severity of IYS symptoms will increase. A promising and sustainable means for long-term IYSV control is the development of cultivars that have an increased tolerance to the virus.

Onion cultivars may differ in their susceptibility to IYSV. However, no onion cultivar or breeding line has been found to be highly resistant to IYSV (Gent et al., 2006). In 2010, Diaz-Montano et al. (2010) screened a large number of onion entries for resistance to thrips and IYSV. Entries differed in their IYSV resistance depending on the year tested. Multani et al. (2009) identified several entries, NMSU 03-52-1, NMSU 04-41, NMSU 04-441, and 'NuMex Jose Fernandez', that expressed fewer IYS symptoms than other entries. Shock et al. (2008) found that 'Joaquin', 'Charismatic', and 'Affirmed' expressed some of the lowest IYSV ratings over a 2-year period. Schwartz et al. (2005) reported significant differences for IYSV incidence among onion cultivars when IYSV incidence ranged from $16 \%$ to $100 \%$ in 2003 and $13 \%$ to $61 \%$ in 2004 . du Toit et al. (2004b) rated 46 onion cultivars for IYSV severity and observed significant differences for IYSV susceptibility. IYSV incidence ranged from $58 \%$ to $97 \%$ among different cultivars. Creamer et al. (2004) reported differences in the IYSV incidence of three onion cultivars in growth chamber tests. The objectives of this study were to screen onion germplasm for IYSV tolerance/resistance in terms of disease severity and incidence to determine the correlation between severity ratings and a measure of virus titer in the plant and to determine the relationship of plant sampling for rating selection with mean plot severity. rate of spread and damage from IYSV and onion thrips (Thrips tabaci L.), the vector of the virus, continues unchecked in the western United States, projected economic impacts could reach $\$ 60$ to $\$ 90$ million (10\% to $15 \%$ loss in farmgate value) in addition to costs incurred from increased pesticide spray applications (W1008: Biology and Management of Iris yellow spot virus and thrips in onions, 2011).

IYSV causes irregular or diamond-shaped straw-colored lesions that develop on leaves and seedstalks (du Toit et al., 2004a; Gent et al., 2004; Schwartz et al., 2002). If IYSV symptoms become severe, bulb size is reduced and the yield of larger bulb classes is reduced (Gent et al., 2004). IYSV is transmitted exclusively by onion thrips (Kritzman et al., 2001; Nagata et al., 1999) that acquire the virus during their larval stage and transmit the virus for their entire life. Control of IYSV requires an integrated approach, including control of the vector, cultural practices, and genetic resistance/tolerance. The primary means of controlling onion thrips is with insecticides, which becomes more challenging when temperatures rise above $30{ }^{\circ} \mathrm{C}$ and if populations of thrips become resistant

\section{Materials and Methods}

Plant materials. Thirteen winter-sown enfor IYSV susceptibility, were selected and assessed for IYS disease symptom severity under field conditions during the 2007 and 2008 growing seasons. These entries consisted of commercial cultivars and experimental breeding lines from the New Mexico State University (NMSU) breeding program. Seeds of entries were sown directly into the field on 14 Feb. 2007 and 15 Feb. 2008. Seedlings were thinned on 25 Apr. 2007 and 17 Apr. 2008 to $10 \mathrm{~cm}$ between two adjacent plants within the row.

Field design and source of inoculum. Field experiments were conducted at the Leyendecker Plant Science Research Center, $2.5 \mathrm{~km}$ south of Las Cruces, NM. A randomized complete block design with four replications for each entry was used. For each experimental unit, two rows spaced $25 \mathrm{~cm}$ apart were sown on the planting bed. Plots were $0.5 \mathrm{~m}$ in width and $6.1 \mathrm{~m}$ in length with $0.6-\mathrm{m}$ alleys between two adjacent plots on the same planting bed. tries, that had not been previously screened 
To ensure that all plants in the test plots had an equal chance to become infected with IYSV, a source of inoculum was brought to the field and the field layout was designed so that IYSV would be spread throughout the field by onion thrips. On the first and last bed of the study and at the front and back borders of the study, IYSV-infected bulbs, from the previous year IYSV evaluation study, were placed in the field to ensure that IYSV inoculum was in the field (Fig. 1). On each alternate bed, IYSV-susceptible cultivars and breeding lines from the NMSU breeding program were sown in October of the previous year to act as disease-spreader rows (Fig. 1). The field layout was designed such that onion thrips would acquire IYSV from the infected bulbs, live on these bulbs until the bulbs developed scapes, and then lost most of their leaf matter. At this time, the thrips would then move to the fall-sown plants. Once these plants matured, then the thrips would move to the plants in the test plots. At each move, thrips would transfer IYSV to those new plants. A similar field layout has been used previously to spread IYSV throughout a test field (Multani et al., 2009).

Field management. The field was managed using standard cultural practices recommended for onion production in southern New Mexico (Corgan et al., 2000, Walker et al., 2009). To ensure an equal chance for all plants to become infected, neither thrips nor any other insect populations were controlled during the study. Weeds were managed either manually or chemically at different stages during the cropping season. Prowl (pendimethalin) (BASF Corporation, Research Triangle Park, NC) was used for the chemical prevention of the weeds. The field was furrowirrigated once per week. Uran-32 (32:0:0, $\mathrm{N}: \mathrm{P}_{2} \mathrm{O}_{5}: \mathrm{K}_{2} \mathrm{O}$; Helena Chemical Co., Collierville, TN) at a rate of $378.5 \mathrm{~L}$ of fertilizer per 40.5 ha was applied to the field at every third irrigation. Each plot was harvested when at least $80 \%$ of the tops had lodged or when all plants in a plot had died as a result of severe necrotic IYSV symptoms.

Disease ratings. To measure disease symptom severity and incidence, onion plants were

\begin{tabular}{|l|l|l|l|l|l|l|l|l|l|l|l|l|l|l|l|l|}
\hline B & B & B & B & B & B & B & B & B & B & B & B & B & B & B & B & B \\
\hline B & A & X & A & X & A & X & A & X & A & X & A & X & A & X & A & B \\
\hline B & A & X & A & X & A & X & A & X & A & X & A & X & A & X & A & B \\
\hline B & A & X & A & X & A & X & A & X & A & X & A & X & A & X & A & B \\
\hline B & A & X & A & X & A & X & A & X & A & X & A & X & A & X & A & B \\
\hline B & A & X & A & X & A & X & A & X & A & X & A & X & A & X & A & B \\
\hline B & A & X & A & X & A & X & A & X & A & X & A & X & A & X & A & B \\
\hline B & A & X & A & X & A & X & A & X & A & X & A & X & A & X & A & B \\
\hline B & A & X & A & X & A & X & A & X & A & X & A & X & A & X & A & B \\
\hline B & A & X & A & X & A & X & A & X & A & X & A & X & A & X & A & B \\
\hline B & B & B & B & B & B & B & B & B & B & B & B & B & B & B & B & B \\
\hline
\end{tabular}

Fig. 1. Field layout of fall-sown, IYSV-susceptible New Mexico State Univ. cultivars and breeding lines (A), IYSV-infected bulbs (B), and test plots (X). IYSV = Iris yellow spot virus. rated for disease symptoms on a scale of 1 to 9 in which 1 indicated no IYSV lesions, 5 indicated $\approx 25 \%$ of leaf tissue was damaged as a result of the coalescing IYSV lesions, and 9 indicated that more than $50 \%$ of leaf tissue was damaged (Multani et al., 2009). Starting on 7 June 2007 and 12 June 2008, plots were rated on a weekly basis for IYSV symptoms until at least $80 \%$ of the plants in a given plot had matured and the plants were ready for harvest. In each plot, two methods were used to select for disease rating. In the first method, 10 randomly selected plants were identified and these same 10 plants were rated each week for disease symptoms. These same 10 plants or "fixed" plants were rated each week to measure disease progression over time within the same plants. In the second method, a new group of 10 plants was randomly selected from each plot for rating at each weekly rating date. This "random" group of plants was rated weekly to get an average disease severity and incidence per plot and to compare the disease ratings between both methods of plant sampling. To ensure that plants were selected randomly, a "random" number generator in SAS (SAS 9.0; SAS Institute Inc., Cary, NC) was used weekly to generate 10 random numbers per plot, which would represent the 10 individual plants per plot to be rated for that particular week. Before generating random numbers, each plant in the plot was given a unique number.

Sample collection. Plant samples were collected on 14 and 28 June 2007 and 19 June and 3 July 2008. Samples consisted of 10 to 15 $\mathrm{g}$ of leaf tissue collected from the tips of two to three outer leaves from the 10 plants within the "fixed" group of each plot. Leaves, that were still vegetatively growing and displaying IYSlike necrotic lesions, were actively sought for samples. The leaf tissue collected from each plant within the plot was kept separate. The tissue samples may or may not have consisted of symptomatic tissue. In addition, samples were collected arbitrarily from 20 IYSVinfected bulbs or plants that were being used as inoculum sources for the study to confirm IYSV presence in the inoculum. Samples were collected in plastic bags, placed in an ice chest, and finally stored at $-4{ }^{\circ} \mathrm{C}$ until testing. Samples were analyzed to confirm the presence of IYSV by the ELISA (Copeland, 1998) and RT-PCR (Cortês et al., 1998). In addition, samples were tested by ELISA to determine a correlation between the disease rating and absorbance value.

Enzyme-linked immunosorbent assay. The assay was performed according to Copeland (1998) with some minor adjustments. Each sample was divided into two equal sections, one for ELISA and one for RT-PCR. An equal amount of tissue from one section, $\approx 1 \mathrm{~g}$, was placed in a 2-mL Eppendorf tube. Tubes were frozen in liquid nitrogen, then samples were ground using a small pestle, and $1 \mathrm{~mL}$ of coating buffer $\left(1.59 \mathrm{~g} \cdot \mathrm{L}^{-1}\right.$ of sodium carbonate, $2.93 \mathrm{~g} \cdot \mathrm{L}^{-1}$ of sodium bicarbonate, and $0.2 \mathrm{~g} \cdot \mathrm{L}^{-1}$ of sodium azide and a $\mathrm{pH}$ of 9.6) was added to each tube. Tubes were centrifuged for $6 \mathrm{~min}$ at $13,500 \mathrm{rpm}$ in an Eppendorf Centrifuge 5415C (Eppendorf North America, Westbury,
NY) to separate the plant debris from the supernatant. Supernatant $(100 \mu \mathrm{L} /$ well $)$ was transferred to each of the two wells in highbinding polystyrene plates (eBioscience, San Diego, CA) for each sample. The plates were incubated for $2 \mathrm{~h}$ at $37^{\circ} \mathrm{C}$. IYSV was detected by using a 1:100 dilution of rabbit IgG antibody against IYSV (Agdia, Elkhart, IN). A 1:2000 dilution of goat antirabbit IgG antibodies (Agdia) conjugated to an alkaline phosphatase enzyme was used as a secondary antibody. Alkaline phosphate substrate $(0.6$ $\mathrm{mg} \cdot \mathrm{mL}^{-1}$ phosphatase substrate of substrate buffer containing $97 \mathrm{~mL} \cdot \mathrm{L}^{-1}$ of diethanolamine and $0.2 \mathrm{~g} \cdot \mathrm{L}^{-1}$ of sodium azide at $\mathrm{pH} 9.8$ ) was added to each well. Plates were incubated for $45 \mathrm{~min}$ to $1 \mathrm{~h}$ at room temperature in the dark. The appearance of a yellow color in the plate wells indicated a positive reaction for IYSV. Absorbence values of plates were measured using an ELISA plate reader operating at 405 nm (Biotron Diagnostics, Inc., Hemet, CA) to obtain the relative absorbance values. As mentioned earlier, leaf samples showing severe IYSV symptoms were used for the positive control. Leaf tissue collected from green bunching onion (purchased at the local grocery store) was used as the negative or healthy control. Samples with ELISA absorbance values, that were greater than the healthy control value plus four times the SD of the healthy control, were considered positive for IYSV (Multani et al., 2009).

Reverse transcription-polymerase chain reaction analysis. Samples, that tested positive for IYSV through ELISA, were further analyzed to confirm the existence of IYSV by performing RT-PCR. Samples taken from healthy plants and green onion leaves (obtained from a local grocery store) were also used as a negative control. Primers, specific to the nucleocapsid (N) gene coded by the small (S)-RNA of IYSV (Evans et al., 2009), were used:

\section{(F) 5' TCAGAAATCGAGAAACTT3' (R) 3' CACCAATGTCTTCAACAATCTT3'}

These primers amplify a 751-bp fragment of the N gene. Total RNA was extracted from $1 \mathrm{~g}$ of leaf tissue using a QIAGEN RNAeasy Plant Mini Kit (QIAGEN Inc., Valencia, CA). RT-PCR was performed using a QIAGEN OneStep RT-PCR Kit (QIAGEN Inc.) in 0.2mL PCR tubes (USA Scientific, Ocala, FL). A GeneAmp PCR System 9700 (Applied Biosystems, Foster City, CA) was used to complete the one-step RT-PCR reaction. Reverse transcription was performed at $50{ }^{\circ} \mathrm{C}$ for 30 min followed by an amplification step with initial incubation at $95{ }^{\circ} \mathrm{C}$ for $15 \mathrm{~min}$ and 30 cycles at $94{ }^{\circ} \mathrm{C}$ for $1 \mathrm{~min}, 45$ to $60^{\circ} \mathrm{C}$ for $45 \mathrm{~s}$, $72{ }^{\circ} \mathrm{C}$ for $1 \mathrm{~min}$, with a final incubation at $72{ }^{\circ} \mathrm{C}$ for $30 \mathrm{~min}$. Products of PCR amplification were resolved on a $1 \%$ agarose gel and analyzed under ultraviolet illumination after staining with $10 \mathrm{mg} \cdot \mathrm{mL}^{-1}$ ethidium bromide.

Statistical analysis. The Proc General Linear Models (GLM) procedure in SAS (SAS 9.0; SAS Institute Inc., Cary, NC) was used to determine if there were differences among entries in different years, sample methods, and their 
interactions for disease severity and incidence percentage. The mean disease rating for each entry was calculated using the "Proc Means" command in SAS. Mean differences among entries on a particular date were determined with Fisher's least significant difference (LSD) test at a probability level of 0.05 . Differences of mean among entries between the two sample methods, "fixed" and "random," on a particular date were also tested. The same tests were done for the percentage of disease incidence. The "Proc GLM" statement in SAS was also used to determine if there were differences between the absorbance values of the entries in different years and their interaction. Means for the absorbance values were calculated, using "Proc Means," for each entry by combining the four replications. To test for differences of mean absorbance value among entries on a particular date, Fisher's LSD mean separation test at a probability level of 0.05 was performed. Because leaf tissue samples were taken from the "fixed" plants, it became possible to correlate the IYS disease rating with the absorbance value of each plant. The "Proc Corr" statement was used to correlate IYS disease severity ratings with the correspondent absorbance values from ELISA in all entries. When testing the entry main effect, $\mathrm{E} \times \mathrm{R}$ interaction mean square was used as the error term.

\section{Results and Discussion}

No disease symptoms were observed on leaves until the end of May during both years. By the beginning of June in both years $(\approx 110 \mathrm{~d}$ after planting), plants started to exhibit a few small, elongated, irregular-shaped chlorotic lesions at different sites on the leaves. These lesions expanded and became light yellow in color by the next 2 to 3 weeks. Lesions later turned necrotic and appeared to be elongated, eye-shaped, or irregular and straw-colored by the first week of July. Leaves were curled and twisted at the site of expanded, dry, and necrotic lesions by the third week of July.

To confirm the presence of IYSV in the bulbs from the previous year that were planted as a source of inoculum, outer leaf tissue samples were collected from these plants and tested with ELISA. These samples showed a positive reaction with polyclonal antisera against IYSV and were used then as the positive control for ELISA. The RT-PCR assay amplified a fragment of expected size with the primer pair, IYSVP1 and IYSVP2, from the ELISA positive samples when tested in both years (Fig. 2A-B). The RTPCR assay did not amplify a fragment of expected size with primer pairs in IYSVnegative samples.

In the rating of entries for IYSV, plants exhibited more severe IYSV symptoms earlier in the season and throughout the entire season in 2007 than in 2008 (Table 1). However, yearly differences were not evident for disease incidence. Disease incidence percentages were similar between years for each rating date except for the last date (Table 1). At the fourth rating date, disease incidence was greater in 2007 than in 2008. This lack of difference between years would suggest that onion thrips were equally effective in each year at moving IYSV throughout the study. This result would also suggest that the yearly differences observed in disease severity did not result from the thrips' ability to move IYSV throughout the study but other factors that influence symptom expression such as environmental conditions. Early in the growing season of both years, daily temperatures were similar between the 2 years (New Mexico Climate Center, 2011). During mid-May and early June, daily temperatures were higher in 2008 than in 2007. Other differences between years such as field plot fertility, irrigation, and/or rainfall amounts may have contributed to the disease differences between years.

Because there were yearly differences in disease severity, results for entries were presented for each year. In 2007, disease symptoms were mild at the first two rating dates and increased in their severity dramatically by the third rating date (Table 1). At most of the rating dates, plants of 'Gelma' and 'Denali' exhibited more severe disease symptoms than plants of the other entries tested. In contrast, plants of NMSU 05-33-1 and NMSU 06-08-1 exhibited less severe symptoms than plants of most other entries. A similar response among entries with respect to disease severity over time was observed in the 2008 test year (Table 1). Although disease symptoms were not as severe in 2008 , plants of 'Denali' and 'Gelma' tended to exhibit more severe symptoms, whereas plants of NMSU 05-33-1 tended to exhibit less severe symptoms than plants of other entries for most rating dates.

By rating 20 plants per plot, a disease incidence percentage could be calculated from the number of plants that expressed IYS symptoms at that rating time. In both years, disease incidence increased drastically over the rating period such that by the fifth rating date, all entries were exhibiting $100 \%$ disease incidence (data not shown). Therefore, disease incidence at the initial rating date would determine how quickly an entry reached a disease incidence of $100 \%$. Of the entries tested, 'Gelma' exhibited a higher disease incidence at the first rating date in both years than other entries tested (Table 1). Conversely, NMSU 05-33-1 exhibited a lower percentage of plants expressing symptoms than other entries rated on the first date in both years. Although the disease incidence of NMSU 0533-1 would reach comparable levels to other entries by the fifth week, the relative disease incidence at each of the four rating dates was lower for NMSU 05-33-1 as a result of the lower initial incidence.

ELISA was used to indirectly measure the amount of virus present in plants and to determine if there were differences among entries in virus titer. In both years and at both sampling dates, ELISA confirmed the presence of IYSV in the positive control and the absence of IYSV in the healthy control (Table 1). These ELISA results were confirmed further through a similar result from RT-PCR analysis (Fig. 2A-B). Based on the absorbance value of the healthy control at first and second sampling dates in

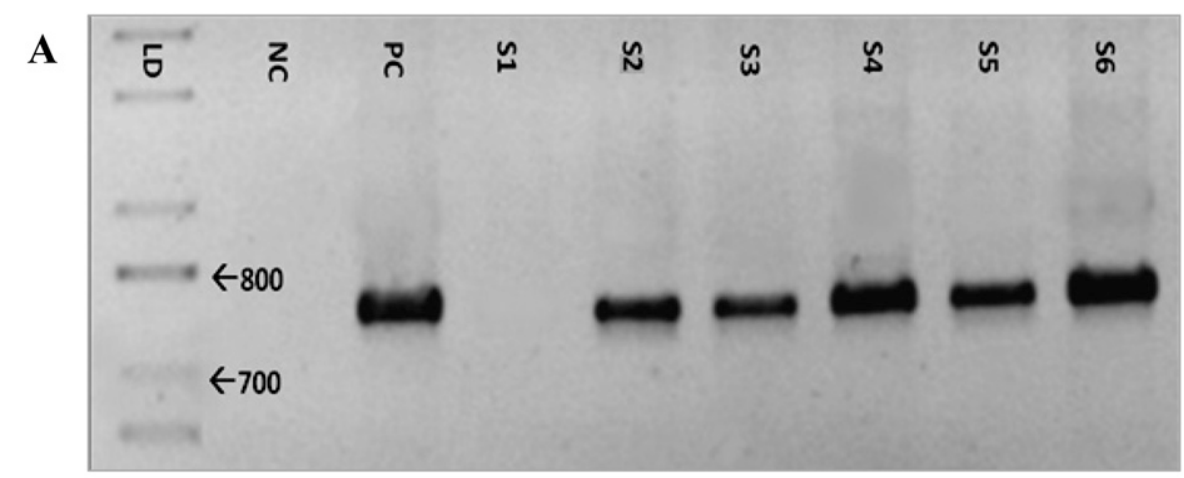

B

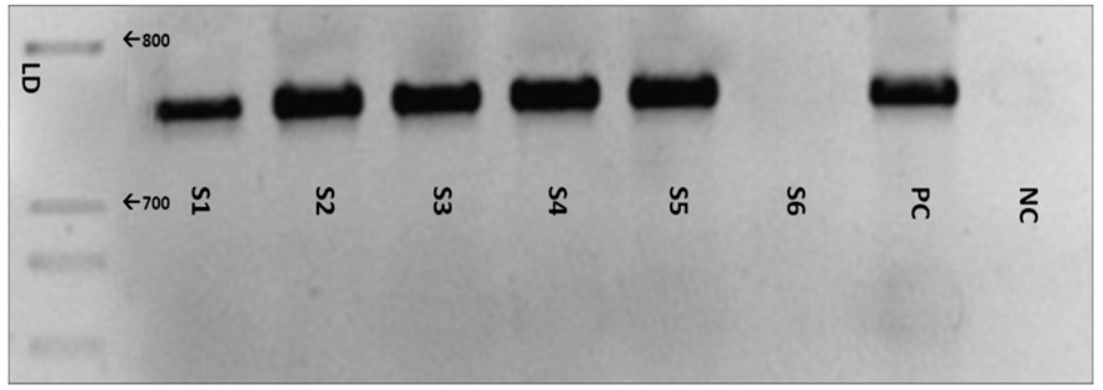

Fig. 2. Agarose gel electrophoresis of reverse transcription-polymerase chain reaction products amplified from tissue samples thought to contain Iris yellow spot virus and collected from winter-sown entries during the 2007 (A) and 2008 (B) cropping seasons. For both seasons, lane LD: 100-bp DNA marker; lane NC: negative control, tissue sample of green onion leaves obtained from local grocery store were used; lane PC: positive control, sample collected from a plant exhibiting severe IYS disease symptoms were used. For 2007 (A), lane S1: sample collected from a healthy plant with a rating of 1 was used; lanes S2 to S6: samples collected from plants with IYS disease rating of 4 to 8, respectively. For 2008 (B), lane S6: sample collected from a healthy plant with a rating of 1 was used; lanes S1 to S5: samples collected from plants with IYS disease rating of 4 to 8 , respectively. IYS = iris yellow spot. 
Table 1. Average Iris yellow spot disease rating and incidence and enzyme-linked immunosorbent assay absorbance values for winter-sown entries collected at different times for the 2007 and 2008 cropping seasons.

\begin{tabular}{|c|c|c|c|c|c|c|c|c|c|c|c|}
\hline \multirow[b]{4}{*}{ Entry $^{\mathrm{w}}$} & \multicolumn{11}{|c|}{ Rating and/or sampling dates (number of days post sowing) ${ }^{\mathrm{z}}$} \\
\hline & \multicolumn{5}{|c|}{ Disease severity rating ${ }^{\mathrm{y}}$} & \multicolumn{4}{|c|}{ Disease incidence $(\%)^{\mathrm{y}}$} & \multicolumn{2}{|c|}{ Absorbance values $^{x}$} \\
\hline & \multicolumn{9}{|c|}{2007} & & \\
\hline & $\begin{array}{l}7 \text { June } \\
\text { (113) }\end{array}$ & $\begin{array}{l}\text { 14 June } \\
(120)\end{array}$ & $\begin{array}{l}21 \text { June } \\
(127)\end{array}$ & $\begin{array}{l}28 \text { June } \\
\text { (134) }\end{array}$ & $\begin{array}{l}5 \text { July } \\
(141)\end{array}$ & $\begin{array}{l}7 \text { June } \\
\text { (113) }\end{array}$ & $\begin{array}{c}\text { 14 June } \\
\text { (120) }\end{array}$ & $\begin{array}{c}21 \text { June } \\
\text { (127) }\end{array}$ & $\begin{array}{c}28 \text { June } \\
\text { (134) }\end{array}$ & $\begin{array}{l}\text { 14 June } \\
(120)\end{array}$ & $\begin{array}{c}28 \text { June } \\
(134)\end{array}$ \\
\hline Denali & 1.6 & 2.6 & 3.9 & 5.9 & 6.6 & 36.3 & 81.3 & 95.0 & 100.0 & $0.050(2.67)$ & $0.290(15.41)$ \\
\hline Gelma & 1.8 & 2.2 & 3.7 & 6.3 & 7.6 & 65.0 & 76.3 & 97.5 & 97.5 & $0.042(2.21)$ & $0.301(16.00)$ \\
\hline NMSU 05-30-2 & 1.5 & 1.8 & 2.7 & 4.4 & 5.1 & 40.0 & 58.8 & 80.0 & 100.0 & $0.034(1.82)$ & $0.172(9.15)$ \\
\hline NMSU 05-32-2 & 1.4 & 1.9 & 3.1 & 5.1 & 5.7 & 36.3 & 55.0 & 77.5 & 98.8 & $0.035(1.86)$ & $0.190(10.07)$ \\
\hline NMSU 05-33-1 & 1.4 & 1.6 & 2.1 & 3.8 & 4.2 & 30.0 & 51.3 & 71.3 & 97.5 & $0.034(1.78)$ & $0.131(6.95)$ \\
\hline NMSU 05-56-2 & 1.5 & 1.8 & 3.1 & 4.7 & 5.3 & 45.0 & 52.5 & 83.8 & 100.0 & $0.036(1.90)$ & $0.159(8.45)$ \\
\hline NMSU 06-05-1 & 1.5 & 1.6 & 2.7 & 4.3 & 5.1 & 45.0 & 37.5 & 78.8 & 98.8 & $0.035(1.85)$ & $0.155(8.22)$ \\
\hline NMSU 06-08-1 & 1.5 & 1.7 & 2.2 & 3.9 & 4.6 & 42.5 & 55.0 & 71.3 & 98.8 & $0.035(1.84)$ & $0.146(7.74)$ \\
\hline NMSU 06-24 & 1.5 & 2.0 & 2.5 & 4.8 & 5.9 & 48.8 & 65.0 & 77.5 & 100.0 & $0.041(2.20)$ & $0.172(9.16)$ \\
\hline NMSU 06-35-1 & 1.6 & 1.9 & 3.0 & 4.5 & 5.0 & 46.3 & 62.5 & 78.8 & 97.5 & $0.044(2.33)$ & $0.191(10.15)$ \\
\hline Polar & 1.6 & 2.0 & 3.3 & 4.8 & 5.9 & 47.5 & 67.5 & 93.8 & 100.0 & $0.039(2.07)$ & $0.180(9.55)$ \\
\hline Utopia & 1.8 & 2.2 & 3.3 & 5.2 & 5.7 & 55.0 & 73.8 & 100.0 & 100.0 & $0.063(3.34)$ & $0.221(11.76)$ \\
\hline Western Giant & 1.4 & 2.0 & 3.2 & 4.8 & 5.7 & 30.0 & 71.3 & 96.3 & 100.0 & $0.038(2.03)$ & $0.188(9.99)$ \\
\hline $\operatorname{LSD}(5 \%)$ & $0.2 * * *$ & $0.4^{* *}$ & $0.8 * * *$ & NS & $0.7 * * *$ & $17.9^{*}$ & $19.9 * *$ & $18.5^{*}$ & NS & $0.014 * *$ & $0.060 * * *$ \\
\hline Positive control $^{\mathrm{v}}$ & & & & & & & & & & $0.063(3.35)$ & $0.097(4.35)$ \\
\hline Healthy control $^{\mathrm{u}}$ & & & & & & & & & & 0.014 & 0.018 \\
\hline \multirow[t]{3}{*}{ Blank $^{\mathrm{t}}$} & & & & & & & & & & 0.000 & 0.000 \\
\hline & \multicolumn{11}{|c|}{2008} \\
\hline & $\begin{array}{l}\text { 12 June } \\
(118)\end{array}$ & $\begin{array}{l}19 \text { June } \\
(125)\end{array}$ & $\begin{array}{c}26 \text { June } \\
\text { (132) }\end{array}$ & $\begin{array}{l}3 \text { July } \\
\text { (139) }\end{array}$ & $\begin{array}{l}\text { 10 July } \\
\text { (146) }\end{array}$ & $\begin{array}{l}\text { 12 June } \\
\text { (118) }\end{array}$ & $\begin{array}{l}\text { 19 June } \\
(125)\end{array}$ & $\begin{array}{c}26 \text { June } \\
\text { (132) }\end{array}$ & $\begin{array}{l}\text { 3 July } \\
\text { (139) }\end{array}$ & $\begin{array}{l}\text { 19 June } \\
(125)\end{array}$ & $\begin{array}{l}\text { 3 July } \\
\text { (139) }\end{array}$ \\
\hline Denali & 1.3 & 2.0 & 2.7 & 3.7 & 4.1 & 51.3 & 73.8 & 90.0 & 91.3 & $0.042(2.02)$ & $0.149(6.61)$ \\
\hline Gelma & 1.2 & 2.5 & 3.0 & 3.8 & 4.1 & 56.3 & 73.8 & 95.0 & 97.5 & $0.078(3.76)$ & $0.152(6.71)$ \\
\hline NMSU 05-30-2 & 1.2 & 1.5 & 2.2 & 2.9 & 3.3 & 33.8 & 55.0 & 85.0 & 95.0 & $0.0291 .41)$ & $0.091(4.00)$ \\
\hline NMSU 05-32-2 & 1.2 & 1.8 & 2.3 & 3.1 & 3.3 & 48.8 & 63.8 & 85.0 & 92.5 & $0.035(1.70)$ & $0.091(4.01)$ \\
\hline NMSU 05-33-1 & 1.1 & 1.3 & 1.6 & 2.4 & 2.3 & 23.8 & 41.3 & 68.8 & 75.0 & $0.033(1.57)$ & $0.056(2.45)$ \\
\hline NMSU 05-56-2 & 1.1 & 1.5 & 2.2 & 2.6 & 3.0 & 30.0 & 56.3 & 75.0 & 87.5 & $0.047(2.27)$ & $0.075(3.34)$ \\
\hline NMSU 06-05-1 & 1.1 & 1.7 & 2.3 & 3.0 & 3.0 & 42.5 & 68.8 & 81.3 & 90.0 & $0.044(2.12)$ & $0.086(3.80)$ \\
\hline NMSU 06-08-1 & 1.2 & 1.5 & 1.9 & 2.9 & 3.1 & 40.0 & 56.3 & 82.5 & 90.0 & $0.029(1.40)$ & $0.091(4.02)$ \\
\hline NMSU 06-24 & 1.0 & 1.8 & 2.6 & 3.1 & 3.4 & 38.8 & 62.5 & 77.5 & 85.0 & $0.038(1.83)$ & $0.099(4.40)$ \\
\hline NMSU 06-35-1 & 1.1 & 1.6 & 2.4 & 3.1 & 3.3 & 31.3 & 72.5 & 86.3 & 91.3 & $0.047(2.30)$ & $0.111(4.89)$ \\
\hline Polar & 1.1 & 1.6 & 2.0 & 2.9 & 3.0 & 30.0 & 56.3 & 81.3 & 92.5 & $0.043(2.08)$ & $0.078(3.47)$ \\
\hline Utopia & 1.2 & 1.7 & 2.5 & 3.6 & 3.5 & 40.0 & 62.5 & 90.0 & 91.3 & $0.038(1.83)$ & $0.126(5.57)$ \\
\hline Western Giant & 1.1 & 1.9 & 2.3 & 3.5 & 3.8 & 46.3 & 62.5 & 91.3 & 93.8 & $0.044(2.11)$ & $0.120(5.31)$ \\
\hline $\operatorname{LSD}(5 \%)$ & NS & $0.5 * *$ & $0.6 * *$ & $0.7 *$ & $0.8^{* *}$ & $18.6^{*}$ & NS & NS & $9.7 *$ & $0.019 * *$ & $0.053 *$ \\
\hline Positive control & & & & & & & & & & $0.063(3.04)$ & $0.095(4.19)$ \\
\hline Healthy control & & & & & & & & & & 0.014 & 0.017 \\
\hline Blank & & & & & & & & & & 0.000 & 0.000 \\
\hline \multicolumn{12}{|l|}{ Year } \\
\hline 2007 mean & 1.5 & 2.0 & 3.0 & 4.8 & 5.6 & 43.7 & 62.1 & 84.7 & 99.1 & $0.040(1.56)$ & $0.190(7.60)$ \\
\hline \multirow[t]{2}{*}{2008 mean } & 1.2 & 1.7 & 2.3 & 3.1 & 3.3 & 39.4 & 61.9 & 83.8 & 90.2 & $0.042(1.53)$ & $0.101(3.68)$ \\
\hline & $* * *$ & $* * *$ & $* * *$ & $* * *$ & $* * *$ & NS & NS & NS & $* * *$ & NS & $* * *$ \\
\hline Plant rating method & & & & & & 2007 & & & & & \\
\hline Fixed mean & 1.5 & 2.0 & 3.1 & 4.7 & 5.6 & 41.0 & 69.2 & 86.7 & 99.0 & & \\
\hline \multirow[t]{3}{*}{ Random mean } & 1.6 & 1.9 & 2.9 & 4.8 & 5.5 & 46.3 & 55.0 & 82.7 & 99.2 & & \\
\hline & $* *$ & $* *$ & NS & NS & NS & NS & $* * *$ & NS & NS & & \\
\hline & \multicolumn{11}{|c|}{2008} \\
\hline Fixed mean & 1.2 & 1.7 & 2.3 & 3.1 & 3.3 & 40.2 & 61.0 & 83.5 & 91.5 & & \\
\hline Random mean & 1.1 & 1.7 & 2.3 & 3.1 & 3.4 & 38.7 & 62.9 & 84.0 & 88.8 & & \\
\hline & NS & NS & NS & NS & NS & NS & NS & NS & NS & & \\
\hline
\end{tabular}

${ }^{\mathrm{z}}$ Seeds of entries were sown directly into the field on 14 Feb. 2007 and 15 Feb. 2008.

${ }^{y}$ Each cell shows the disease severity rating or disease incidence of a entry on a particular date averaged over four replications. Ten fixed and 10 randomly selected plants from each plot were rated for IYS symptoms based on a scale of 1 (no disease symptom) to 9 ( $50 \%$ or more of the leaf tissue showing symptoms).

${ }^{x}$ Each cell shows the mean enzyme-linked immunosorbent assay absorbance value for an entry obtained by averaging the absorbance values from two wells of four different tissue samples taken from "fixed" plants over three replicated plots of that entry. Values in parentheses are the amount that the entry absorbance value is greater than the healthy control $+4 \mathrm{sD}$.

w'Denali' and 'Polar' are from Nunhems USA (Palma, ID); 'Western Giant' is from Sakata Seed America, Inc. (Morgan Hill, CA); 'Gelma' and 'Utopia' are from Seminis Vegetable Seeds, Inc. (Oxnard, CA).

${ }^{\mathrm{v}}$ Tissue samples from the previous year infected onion plants that were rated very high for IYS severity were used as a positive control.

"Green onion leaves obtained from a local grocery store were used as a healthy control.

${ }^{\mathrm{t}}$ Coating buffer was used as a blank.

NS, *,**,***Non-significant F-test at $P=0.05$, significant F-test at $P=0.05, P=0.01$, and $P=0.001$, respectively.

IYS $=$ iris yellow spot; LSD = least significant difference. 
each year, all entries would be considered positive for IYSV (Table 1). At the first sampling date in 2007, plants of 'Utopia' exhibited an absorbance value than plants of all other entries except 'Denali', whereas at the first sampling date in 2008, plants of 'Gelma' exhibited a higher absorbance value than plants of other entries. In each year, absorbance values increased drastically from the first to the second sampling date. Although there was no difference in the absorbance value of plants from NMSU 05-33-1 and plants from most other entries sampled at the first date in both years, plants of NMSU 05-33-1 sampled at the second date exhibited a lower absorbance value than plants from a few entries.

For all entries sampled in each year and at each date, a strong, positive correlation was observed between disease severity rating and absorbance value such that as the severity rating increased, so did the absorbance value and vice versa (Table 2 ). This result would suggest that the increase in disease severity is directly a function of the increase in virus levels within the plant. In general, the correlation between these two factors became stronger and more positive as disease symptoms became more severe.

For each plot, 10 randomly selected plants and 10 of the same plants (fixed) were rated each week. The fixed plants were selected so that disease progression could be observed over time on these plants and a correlation between a disease severity rating and absorbance values could be determined for these plants. The two separate sample methods were selected to determine if any differences in plot disease severity or incidence existed based on plant sampling. In 2007 and 2008, disease severity ratings and incidence percentages were similar between the two rating methods (Table 1). The only differences between the two methods were observed in 2007. Small differences in disease severity were observed at the first and second rating dates. On the second rating date, the fixed plant method exhibited a higher disease incidence than the random plant method. Based

Table 2. Pearson correlation coefficients between Iris yellow spot disease severity ratings and enzymelinked immunosorbent assay absorbance values for winter-sown entries, sown in the winter of 2007 and 2008 cropping seasons.

\begin{tabular}{|c|c|c|c|c|}
\hline \multirow[b]{2}{*}{ Entry } & \multicolumn{4}{|c|}{ Sampling dates (number of days post sowing) ${ }^{\mathrm{z}}$} \\
\hline & $\begin{array}{c}14 \text { June } 2007 \\
\text { (120) }\end{array}$ & $\begin{array}{l}28 \text { June } 2007 \\
(134)\end{array}$ & $\begin{array}{l}19 \text { June } 2008 \\
(125)\end{array}$ & $\begin{array}{c}3 \text { July } 2008 \\
(139)\end{array}$ \\
\hline Denali & $0.78^{* * *}$ & $0.98 * * *$ & $0.74 * * *$ & $0.96^{* * *}$ \\
\hline Gelma & $0.68 * * *$ & $0.97 * * *$ & $0.93 * * *$ & $0.77 * * *$ \\
\hline NMSU 05-30-2 & $0.74 * * *$ & $0.96 * * *$ & $0.76 * * *$ & $0.92 * * *$ \\
\hline NMSU 05-32-2 & $0.60 * * *$ & $0.95 * * *$ & $0.65 * * *$ & $0.92 * * *$ \\
\hline NMSU 05-33-1 & $0.75 * * *$ & $0.93 * * *$ & $0.70 * * *$ & $0.85 * * *$ \\
\hline NMSU 05-56-2 & $0.63 * * *$ & $0.94 * * *$ & $0.92 * * *$ & $0.75 * * *$ \\
\hline NMSU 06-05-1 & $0.64 * * *$ & $0.94 * * *$ & $0.84 * * *$ & $0.92 * * *$ \\
\hline NMSU 06-08-1 & $0.65 * * *$ & $0.95 * * *$ & $0.66 * * *$ & $0.94 * * *$ \\
\hline NMSU 06-24 & $0.73 * * *$ & $0.96 * * *$ & $0.72 * * *$ & $0.93 * * *$ \\
\hline NMSU 06-35-1 & $0.78 * * *$ & $0.97 * * *$ & $0.89 * * *$ & $0.96^{* * *}$ \\
\hline Polar & $0.70 * * *$ & $0.96 * * *$ & $0.89 * * *$ & $0.92 * * *$ \\
\hline Utopia & $0.68 * * *$ & $0.96 * * *$ & $0.72 * * *$ & $0.96 * * *$ \\
\hline Western Giant & $0.68 * * *$ & $0.97 * * *$ & $0.81 * * *$ & $0.94 * * *$ \\
\hline
\end{tabular}

zRating from the "fixed" plant sample method was correlated with the absorbance value of the same plant on any given date. Entries were replicated four times.

$* * * *$ Significant at $P=0.001$.

on these results, plant sampling within the plot for rating does not influence disease severity rating or incidence values.

Of the entries tested, NMSU 05-33-1 showed the most promise for developing an IYSV-tolerant onion cultivar. In both years, this entry developed IYS symptoms at a slower rate and expressed less severe symptoms than other entries. At the start of the rating time, NMSU 05-33-1 expressed a lower disease incidence than other entries, i.e., fewer plants were expressing IYS symptoms. Even by the second and third rating dates, there were some plants that had not expressed any disease symptoms yet. These plants would have contributed to the low severity rating for this entry. Clearly, there were plants within this entry that expressed a higher tolerance to IYSV by not expressing symptoms as readily as other entries. The tolerance was not absolute because these plants eventually expressed symptoms by the last rating date when disease incidence was $100 \%$ in both years.

A partial explanation for this delay in symptom expression could be the lack of plant attractiveness to onion thrips. They are attracted to onion leaves that possess a high degree of wax deposition on their leaf surface (Coudriet et al., 1979; Jones et al., 1934). This high amount of wax gives the leaf a bluish cast compared with those leaves that have little wax, often referred to as semiglossy, and leaves appear to be green to light green in color. NMSU 05-33-1 has green to light green leaves. At the beginning of the season, onion thrips would be attracted first to those onion leaves that are darker or bluish in color. This thrips movement could result in a higher disease incidence early in the season for those cultivars that have bluish-colored leaves. In our study, 'Gelma', which possesses bluish-colored leaves, exhibited a higher disease incidence at the first rating date than NMSU 05-33-1 when entries were tested in both years. This high disease incidence at the first rating date would warrant an earlier disease rating for those onion cultivars deemed highly attractive to onion thrips. Another explanation for the delay in symptom expression observed for plants of NMSU 05-33-1 could be greater stress tolerance of these plants as compared with plants of other entries. This explanation assumes equal thrips feeding among entries such that all plants could possess the same virus titer by thrips movement and the equal ability of virus replication within plants of all entries. The initial absorbance values observed at the second rating date suggest a similar virus titer in plants among entries and equal movement of the virus among plants of all entries. At this rating date, entries exhibited differences in disease severity that would suggest that differences in stress tolerance exist among entries. With respect to IYS, symptom expression is partially a function of the degree of plant stress because asymptomatic plants have been confirmed to be positive for IYSV (Diaz-Montano et al., 2010; Gent et al., 2004).

NMSU 05-33-1 may also limit virus replication within the plant. At the first sampling date in both years, the absorbance value of NMSU 05-33-1 was similar to the value of other entries. For both years, the absorbance value of NMSU 05-33-1 at the second sampling date would suggest that IYSV was present in plants, however not at the same level of other entries.

Of the entries tested, 'Gelma' and 'Denali' exhibited the most severe IYS symptoms in each year. Both of these entries exhibited a higher disease incidence than other entries early in the year although disease symptoms were mild at this time. This observation would suggest that onion thrips had been attracted to plants of these entries and had been spreading virus among these plants before the first rating date. The lack of more severe symptoms probably resulted from the absence of environmental conditions that would cause plant stress. The earlier infection of plants from these two entries would be expected to show as higher absorbance values and, indirectly, as higher virus titer. Both entries did exhibit higher absorbance values than a number of other entries at both sample dates in each year. With this potential earlier infection and higher virus titer, disease symptom severity and incidence would be expected to be higher for 'Denali' and 'Gelma' because plants of these entries are further along in disease development than plants of other entries. Because the main impact of IYSV is on onion bulb yield, any earlier disease development relative to plant development stage can cause a reduction in bulb size and yield. Conversely, a delay in disease development relative to plant development, as was observed for NMSU 05-33-1, could reduce the impact of IYSV on bulb yield. All of the entries tested in this study matured at the same time, because bulb maturity was the determining factor for ending disease ratings. Plants of these entries could be considered to be at the same developmental stage throughout the growing season.

For each entry tested in each year, a strong, positive correlation was observed between disease severity rating and absorbance value. If it is assumed that the absorbance value is an 
indirect measure of virus titer, then the disease symptoms observed are a direct representation of the amount of virus in the plant and vice versa. This result is contrary to the result found by a previous study (Multani et al., 2009). In that study, plants used for disease rating and tissue sampling were not the same and, as a result, no strong, positive correlation was observed between disease severity and absorbance value. When plants rated and sampled were the same, a strong, direct relationship was observed. Even with the strong relationship between disease rating and absorbance values, absorbance values do not account for all of the variation in disease ratings. Some explanations for this result could be that symptom expression is partially a function of plant stress, as mentioned earlier, and that the absorbance values are not a direct measure of virus titer within the plant.

In conclusion, NMSU 05-33-1 appears to delay the onset of symptoms and detection of IYSV relative to other entries. 'Denali' and 'Gelma' appear to be more susceptible to IYSV because plants exhibit earlier symptom expression, higher disease severity, and higher virus levels than plants of other entries. Entries do exhibit differences in disease development rates that may be partially related to the attractiveness of plants to onion thrips. For IYSV-susceptible cultivars, disease rating earlier in the season may be needed. Absorbance values and disease severity were strongly positively correlated with each other. As virus levels increase within the plant, an increase in symptom expression would be expected. Plant sampling does not appear to influence mean disease severity; however, for correlating disease rating and absorbance values and for measuring disease progress over time, plant sampling method becomes very important.

\section{Literature Cited}

Copeland, R. 1998. Assaying levels of plant virus by ELISA, p. 455-460. In: Foster, G.D. and S.C. Taylor (eds.). Methods in molecular biology. Vol. 81. Plant virology protocols: From virus isolation to transgenic resistance. Humana Press, Totowa, NJ.

Corgan, J.N., M.M. Wall, C.S. Cramer, T. Sammis, B. Lewis, and J. Schroeder. 2000. Bulb onion culture and management. New Mexico Coop. Ext. Serv. Circ. 563.

Cortês, I., I.C. Livieratos, A. Derks, D. Peters, and R. Kormelink. 1998. Molecular and serological characterization of Iris yellow spot virus, a new and distinct tospovirus species. Phytopathology 88:1276-1282.

Coudriet, D.L., A.N. Kishaba, J.D. McCreight, and W.G. Bohn. 1979. Varietal resistance in onions to thrips (Thysanoptera, Thripidae). J. Econ. Entomol. 72:614-615.

Creamer, R., S. Sanogo, A. Moya, J. Romero, R. Molina-Bravo, and C. Cramer. 2004. Iris yellow spot virus on onion in New Mexico. Plant Dis. 88:1049.

Crowe, F.J. and H.R. Pappu. 2005. Outbreak of Iris yellow spot virus in onion seed crops in central Oregon. Plant Dis. 89:105.

Diaz-Montano, J., M. Fuchs, B.A. Nault, and A.M. Shelton. 2010. Evaluation of onion cultivars for resistance to onion thrips (Thysanoptera:Thripidae) and Iris yellow spot virus. J. Econ. Entomol. 103:925-937.

du Toit, L.J., H.R. Pappu, K.L. Druffel, and G.Q. Pelter. 2004a. Iris yellow spot virus in onion bulb and seed crops in Washington state. Plant Dis. $88: 222$

du Toit, L.J., G.Q. Pelter, and H.R. Pappu. 2004b. IYSV challenges to the onion seed industry in Washington, p. 213-217. In: Swift, C. (ed.). Proc. 2004 Natl. Allium Res. Conf., Grand Junction, $\mathrm{CO}$.

Evans, C.K., S. Bag, E. Frank, J. Reeve, C. Ransom, D. Drost, and H.R. Pappu. 2009. Green foxtail (Setaria viridis), a naturally infected grass host of Iris yellow spot virus in Utah. Plant Dis. 93:670-671.

Gent, D.H., L.J. du Toit, S.F. Fichtner, S.K. Mohan, H.R. Pappu, and H.F. Schwartz. 2006. Iris yellow spot virus: An emerging threat to onion bulb and seed production. Plant Dis. 90:1468-1480.

Gent, D.H., H.F. Schwartz, and R. Khosla. 2004. Distribution and incidence of Iris yellow spot virus in Colorado and its relation to onion plant population and yield. Plant Dis. 88:446-452.

Hall, J.M., S.K. Mohan, E.A. Knott, and J.W. Moyer. 1993. Tospoviruses associated with scape blight of onion (Allium cepa) seed crops in Idaho. Plant Dis. 77:952.

Hoepting, C.A., H.F. Schwartz, and H.R. Pappu. 2007. First report of Iris yellow spot virus on onion in New York. Plant Dis. 91:327.

Jones, H.A., S.F. Bailey, and S.L. Emsweller. 1934. Thrips resistance in onion. Hilgardia 8:215252.

Kritzman, A., M. Lampel, B. Raccah, and A. Gera. 2001. Distribution and transmission of Iris yellow spot virus. Plant Dis. 85:838-842.

MacIntyre Allen, J.K., C.D. Scott-Dupree, J.H. Tolman, and C.R. Harris. 2005. Resistance to Thrips tabaci to pyrethroid and organophosphorus insecticides in Ontario, Canada. Pest Manag. Sci. 61:809-815.

Martin, N.A., P.J. Workman, and R.C. Butler. 2003. Insecticide resistance in onion thrips
(Thrips tabaci) (Thysanoptera: Thripidae). N. Z. J. Crop Hortic. Sci. 31:99-106.

Miller, M.E., R.R. Saldana, M.C. Black, and H.R. Pappu. 2006. First report of Iris yellow spot virus on onion (Allium cepa) in Texas. Plant Dis. 90:1359.

Mullis, S.W., D.B. Langston, Jr., R.D. Gitaitis, J.L. Sherwood, A.C. Csinos, D.G. Riley, A.N. Sparks, R.L. Torrance, and M.J. Cook. 2004. First report of Vidalia onion (Allium cepa) naturally infected with Tomato spotted wilt virus and Iris yellow spot virus (Family Bunyaviridae, Genus Tospovirus) in Georgia. Plant Dis. 88:1285.

Multani, P.S., C.S. Cramer, R.L. Steiner, and R. Creamer. 2009. Screening winter-sown onion entries for Iris yellow spot virus tolerance. HortScience 44:627-632.

Nagata, T., A.C.L. Almeida, R. de O. Resende, and A.C. de Avila. 1999. The identification of the vector species of iris yellow spot tospovirus occurring on onion in Brazil. Plant Dis. 83:399.

New Mexico Climate Center. 2011. NMCC Climate Data Display Selection. 18 Jan. 2011. $<\mathrm{http} / /$ weather.nmsu.edu/cgi-shl/cns/uberpage.pl>.

Pappu, H. and M. Matheron. 2008. Characterization of Iris yellow spot virus from onion in Arizona. Plant Health Prog. doi: 10.1094/PHP-20080711-01-BR.

Poole, G.J., H.R. Pappu, R.M. Davis, and T.A. Turini. 2007. Increasing outbreaks and impact of Iris yellow spot virus in bulb and seed onion crops in the Imperial and Antelope Valleys of California. Plant Health Prog. doi: 10.1094/PHP2007-0508-01-BR.

Schwartz, H.F., W.M. Brown, Jr., T. Blunt, and D.H. Gent. 2002. Iris yellow spot virus on onion in Colorado. Plant Dis. 86:560.

Schwartz, H.F., D.H. Gent, S.F. Fichtner, R.W. Hammon, and R. Khosla. 2005. Integrated management of Iris yellow spot virus in onion, p. 207-212. In: Swift, C. (ed.). Proc. 2004 Natl Allium Res. Conf., Grand Junction, CO.

Shelton, A.M., B.A. Nault, J. Plate, and J.Z. Zhao. 2003. Regional and temporal variation in susceptibility to $\lambda$-cyhalothrin in onion thrips, Thrips tabaci (Thysanoptera: Thripidae), in onion fields in New York. J. Econ. Entomol. 96:1843-1848.

Shock, C.C., E.B.G. Feibert, L.B. Jensen, S.K. Mohan, and L.D. Saunders. 2008. Onion variety response to Iris yellow spot virus. HortTechnology 18:539-544.

Walker, S., J. Ashigh, C.S. Cramer, T. Sammis, and B. Lewis. 2009. Bulb onion culture and management for southern New Mexico. New Mexico Coop. Ext. Serv. Circ. 563.

W1008: Biology and Management of Iris yellow spot virus and thrips in onions. 2011. Homepage: W1008. 26 Jan. 2011. <http://www.nimss.umd. edu/homepages/home.cfm?trackID=9416>. 